\title{
EQUITY
}

Vol. 24, No.2, 2021, 243-260

DOI: 10.34209 /equ.v24i2.2686

P-ISSN 0216-8545 | E-ISSN 2684-9739

Diunggah : Maret 2021

Diterima : Desember 2021

Dipublikasi : Januari 2022

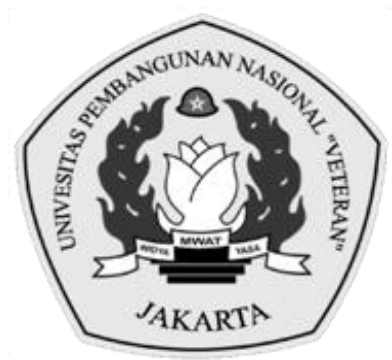

\section{PENGARUH ENTERPRISE RISK MANAGEMENT TERHADAP KINERJA KEUANGAN PERUSAHAAN}

\author{
Muhammad Faisal Anfasah Mutaz ${ }^{1}$, Erna Hernawati2*, Agus Maulana ${ }^{3}$ \\ 11m.faisalmutaz@upnvj.ac.id, 2erna.hernawati@upnvj.ac.id, \\ 3agus.maulana@upnvj.ac.id \\ 1,2,3Universitas Pembangunan Nasional Veteran Jakarta, Indonesia \\ *Penulis Korespondensi
}

\begin{abstract}
Abstrak
Penelitian ini bertujuan untuk mengetahui pengaruh enterprise risk management (ERM) terhadap kinerja perusahaan. Penelitian ini menggunakan perusahaan BUMN non-keuangan yang terdaftar pada BEI pada tahun 2015-2019. Dengan menggunakan metode purposive sampling jumlah sampel yang didapat yaitu sebanyak 16 perusahaan. Pengukuran kinerja perusahaan diproksikan dengan ROA, sedangkan indikator ERM diukur dengan konten analisis dengan jumlah 6 indikator yaitu Sentralitas CRO (Chief Risk Officer), pelatihan komite risiko, rapat komiter risiko, frekuensi penilaian risiko, level penilaian risiko, dan metode peniliaian risiko. Pengujian hipotesis dalam penelitian ini menggunakan Analisis Regresi Linier Berganda dengan program SPSS dan tingkat signifikansi 0,05 (5\%). Hasil dari pengujian didapatkan (1) kinerja perusahaan tidak dipengaruhi signifikan oleh sentralitas CRO (2) kinerja perusahaan tidak dipengaruhi signifikan oleh pelatihan komite risiko (3) kinerja perusahaan dipengaruhi signifikan oleh rapat komite risiko (4) kinerja perusahaan tidak dipengaruhi signifikan oleh frekuensi penilaian risiko (5) kinerja perusahaan tidak dipengaruhi signifikan oleh level penilaian risiko (6) kinerja perusahaan tidak dipengaruhi signifikan oleh metode penilaian risiko.
\end{abstract}

Kata Kunci: Komite Risiko; Penilaian Risiko; Kinerja Perusahaan.

\begin{abstract}
This research is a quantitative study with the aim of knowing the effect of enterprise risk management on firm performance. This study uses non-financial state-owned companies listed on the IDX on 2015-2019. The selection used purposive sampling after determining the number of samples that can be accepted, namely as many as 16 companies. Hypothesis testing in this study used Multiple Linear Regression Analysis with the SPSS program and a significance level of 0.05 (5\%). The results of the test are (1) firm performance is not significantly affected by CRO centrality (2) firm performance is not significantly affected by risk committee training (3) firm performance is significantly influenced by risk committee meetings (4) firm performance is not significantly affected by the frequency of assessments risk (5) firm performance is not significantly affected by the level of risk assessment (6) firm performance is not significantly affected by risk assessment methods.
\end{abstract}

Keywords: Risk Committee; Risk Assessment; Firm Performance.

Mengutip ini sebagai: Mutaz, M.F.A., Hernawati, E. \& Maulana, A. 2021. Pengaruh Enterprise Risk Management Terhadap Kinerja Keuangan Perusahaan. Equity, 24(2), 243-260. doi.org/10.34209/equ.v24i2.2686 


\section{PENDAHULUAN}

Kinerja perusahaan merupakan tolak ukur digunakan umumnya oleh investor dalam pertimbangan mereka untuk melakukan investasi. Kinerja yang baik dapat meningkatkan nilai perusahaan (Adi, 2020) Semakin baik kinerja yang ditunjukkan perusahaan berdampak pada semakin meningkatnya kepercayaan investor untuk menanamkan modal di perusahaan tersebut. Faktor-faktor yang mempengaruhi kinerja perusahaan sangatlah beragam. Namun dalam fokus penelitian ini lebih merujuk kepada faktor kapabilitas perusahaan dalam melakukan manajemen risiko sehingga nantinya akan mempengaruhi hasil kinerja mereka.

Terdapat 11 perusahaan non-keuangan dalam indeks BUMN20 sudah melaporkan kinerjanya. 9 dari 11 emiten tersebut, mencetak net income positif, dan dua emiten lainnya mendapat kerugian. Beberapa emiten sempat mengalami kerugian di periode 2018 dan selama periode 2019 berhasil meraup untung. Perolehan kinerja terbaik ditorehkan oleh PT Telkom Indonesia dalam hal pertumbuhan pendapatan (Ayuningtyas, 2019). Berdasarkan fenomena di atas, mencerminkan pentingnya perusahaan dalam mengelola risiko yang ada untuk mencegah dan mengurangi dampak terhadap penurunan kinerja yang dicapai perusahaan. Perusahaan yang tidak memiliki pengelolaan risiko yang baik pastinya akan kesulitan dalam peningkatan pendapatan pada kondisi yang sangat tidak pasti dan akan meningkatkan kemungkinan mengalami kerugian akibat risiko yang tidak dikelola dengan baik. Untuk mengatasi risiko, menurut data hasil survei CRMS, menunjukkan bahwa pada tahun 2019 mayoritas instansi di Indonesia (instansi pemerintah maupun swasta) telah menerapkan manajemen risiko terintegrasi atau enterprise risk management (ERM). Hal ini terlihat dari sebanyak $76,12 \%$ responden yang menyatakan bahwa organisasi tempat mereka bekerja telah menerapkan manajemen risiko terintegrasi atau ERM (CRMS, 2019).

Beranjak dari fenomena di atas, peneliti menelusuri penelitian terdahulu yang terkait kinerja perusahaan dan ditemukan beberapa penelitian, seperti penelitian yang dilakukan oleh Malik et al., (2020) sampel perusahaan yang terdaftar di pasar modal Inggris menunjukkan terdapat pengaruh signifikan terhadap kinerja perusahaan oleh ERM. Hasil penelitian ini sependapat dengan penelitian menurut Songling et al., (2018); Sax \& Torp (2015); Florio \& Leoni (2017); dan Kashif Shad \& Lai (2019). Namun hasil yang berbeda ditunjukkan menurut penelitian Adi (2020); Otero González et al., (2020); Ali et al., (2019); dan Senol \& Karaca (2017) menyatakan sebaliknya dimana kinerja perusahaan tidak dipengaruhi secara signifikan oleh ERM. Perbedaan hasil penelitian di atas menjadi faktor gap research yang mendorong peneliti untuk melakukan lanjutan penelitian. Penelitian ini mencoba mengguankan data yang berbeda dari penelitian sebelumnya, dan juga menggunakan indikator ERM yang digabungkan dari penelitian penelitian Florio \& Leoni (2017) dan Cavezzali \& Gardenal (2015).

Berdasarkan penelitian terdahulu dan fenomena diatas dapat disimpulkan bahwa adanya kemungkinan pengaruh dari ERM terhadap kinerja keuangan perusahaan. Tujuan dari penelitian ini adalah untuk menguji apakah ERM berpengaruh kinerja keuangan perusahaan. Terdapat beberapa variabel terkait enterprise risk management didasarkan pada penelitian terdahulu yang akan diuji 
pengaruhnya terhadap kinerja keuangan perusahaan, seperti sentralitas CRO (Chief Risk Officer), pelatihan komite risiko, rapat komite risiko, frekuensi penilaian risiko, level penilaian risiko, dan metode penilaian risiko.

\section{TINJAUAN PUSTAKA}

\section{Teori Keagenan}

Teori ini adalah teori yang memberikan penggambaran terkait konflik antara manajemen sebagai agent dan pemegang saham sebagai principal. Teori keagenan pertama kali diperkenalkan oleh (Jensen \& Meckling, 1976) yang menjelaskan bahwa terdapat hubungan keagenan antara shareholder atau pemegang saham sebagai principal dan manajemen perusahaan sebagai agent. Menurut teori ini, manajemen adalah pihak yang dikontrak untuk memenuhi kepentingan principal oleh para pemegang saham atau shareholder. Manajemen diberikan wewenang oleh pemegang saham untuk membuat keputusan terbaik sehingga setiap keputusan yang diambil, manajemen harus bertanggungjawab secara penuh.

Berdasarkan teori agensi, Enterprise risk management merupakan salah satu cara yang digunakan manajemen untuk memenuhi keinginan pemilik saham dalam peningkatan kinerja perusahaan dicapai melalui keberhasilan dalam pengelolaan risiko. Karena dari setiap risiko yang dihadapi perusahaan terdapat peluang yang mampu meningkatkan kinerja ataupun membuat kegagalan dalam perusahaan, sehingga tata kelola risiko yang memiliki kerangka kerja yang baik mampu memanfaatkan peluang tersebut.

\section{Enterprise Risk Management}

Manajemen adalah proses mengarahkan dan memfasilitasi pekerjaan orang yang diorganisir dalam kelompok formal untuk mencapai tujuan yang diinginkan (Millet, 1954). Sedangkan menurut Terry (1977), Manajemen adalah pencapaian tujuan yang telah ditentukan melalui upaya orang lain. Berdasarkan dengan setiap definisi manajemen berlandaskan pendapat ahli diatas maka dapat ditarik sebuah kesimpulan seni yang memiliki sebuah proses runtut dan sistematis dalam pencapaian tujuan atau penyelesaian pekerjaan dengan menggunakan upaya orang lain disebut manajemen.

Terdapat beberapa definisi risiko menurut Vaughan \& Elliot (1978) seperti Risiko adalah kans kerugian; Risiko adalah kemungkinan kerugian; Risiko adalah ketidakpastian; Risiko adalah penyebaran aktual dari hasil yang diharapkan; Risiko adalah kemungkinan hasil yang berbeda dari yang diharapkan. Adapun unsur penilaian risiko menurut Curtis \& Carey, (2012) dibagi berdasarkan tingkat pengaruhnya, tingkat kemungkinan terjadinya, tingkat kerentanan, tingkat kecepatan mencapai puncak, dan risiko inheren \& residual. Dalam penilaian risiko terdapat dua metode yakni kualitatif dan kuantitatif. Dimana kedua metode masing-masing memiliki kelebihan dan kekurangan.

Manajemen risiko dalam arti luas merupakan ilmu yang membahas bagaimana organisasi atau perusahaan dapat menyelesaikan permasalahan yang ada dengan ditempatkan secara komprehensif dan sistematis dengan berbagai 
metode manajemen (Fahmi Irham, 2016). Sedangkan menurut Pranatha, Moeljadi, \& Hernawati (2019), Salah satu metode pengelolaan struktural atas ketidakpastian terkait ancaman; serangkaian aktivitas manusia yang meliputi: penilaian risiko, perumusan strategi pengelolaan, dan penggunaan otorisasi atau pengelolaan sumber daya untuk memitigasi risiko disebut manajemen risiko.

Berdasarkan beberapa definisi yang telah dijabarkan terkait manajemen, risiko dan pendapat ahli tentang manajemen risiko, penulis menyimpulkan bahwa manajemen risiko adalah sebuah usaha yang dilakukan dalam pencapaian tujuan perusahaan atau proses lainnya dengan melakukan tiap fungsi dalam manajemen terkait penanggulangan risiko, yakni mencakup kegiatan perencanaan, pengorganisasian, penggerakan/pengerahan, dan pengendalian untuk tercapai secara efektif dan efisien.

Definisi manajemen risiko terintegrasi korporasi (ERM) adalah suatu proses strategis yang dipengaruhi unsur internal perusahaan untuk diterapkan dalam lingkungan perusahaan dengan tujuan mengidentifikasi kemungkinan yang mampu memengaruhi organisasi untuk mencapai tujuan (COSO ERP, 2004). Perbedaan mendasar manajemen risiko tradisional dengan ERM ini adalah ERM memberikan penilaian risiko yang lebih terintegrasi dan secara mendetail. Jika ERM diterapkan pada sebuah perusahaan, risiko akan mampu diidentifikasikan pada tingkatan terkecil di perusahaan seperti ketersediaan stok barang pada perusahaan manufaktur. Perusahaan akan melakukan analisis pengiriman, analisis supply chain, evaluasi dari proses produksi. ERM ini akan menjabarkan apa saja yang mampu mencegah ketersediaan stok barang untuk dijual oleh perusahaan. Risikonya seperti terdapat gangguan produksi, ketiadaan bahan baku, atau terdapat masalah pada proses distribusi.

Diawal pembentukannya COSO menggunakan kerangka kerja Enterprise Risk Management-Integrated Framework, seiring berjalannya waktu setelah ERM diterima dan diterapkan oleh perusahaan, dirumuskan kerangka kerja baru untuk meningkatkan kemampuan perusahaan dalam pengelolaan risiko. Kerangka kerja terbaru dari ERM menurut COSO adalah Enterprise Risk Management-Integrating with Strategy and Performance yang memiliki lima komponen baru menjabarkan pentingnya sistem ERM dalam proses perencanaan strategi dan menerapkannya di seluruh elemen organisasi disebabkan risiko mampu memengaruhi dan menyeleraskan strategi dan kinerja seluruh departemen di dalam perusahaan (COSO, 2017). Berikut kelima komponen menurut kerangka kerja ERM menurut COSO yaitu (1) Tata Kelola dan Budaya (Governance and Culture); (2) Strategi dan Penetapan Tujuan (Strategy and Objective-Setting); (3) Kinerja (Performance); (4) Review dan Revisi (Review and Revision); (5) Informasi, Komunikasi, dan Pelaporan (Information, Communication, and Reporting).

\section{Sentralitas CRO}

CRO (Chief Risk Officer) merupakan salah satu fungsi dalam perusahaan yang menjadi motor pengelolaan risiko di perusahaan. Sentralitas dalam pengertian ini adalah bentuk apresiasi dari perusahaan terhadap CRO dengan menunjukkan memberikan gaji atau remunerasi lebih besar dibanding dengan CFO perusahaan tersebut. Menurut Bertinetti et al., (2013) sentralitas CRO adalah seberapa besar urgensi kepentingan yang dimiliki oleh perusahaan khususnya 
terkait pengukuran risiko perusahaan. Dimana CRO yang diberi remunerasi lebih besar dari CFO cenderung memberikan performa yang baik dalam meningkatkan kinerja perusahaan dengan mampu untuk memberikan penilaian yang tepat atas risiko perusahaan. Berdasarkan pengertian diatas maka sentralitas CRO adalah indikator yang menunjukkan berapa besarnya apresiasi perusahaan terhadap CRO. Otero González et al. (2020) yang meneliti di Spanyol tidak menemukan pengaruh sentralitas CRO terhadap kinerja perusahaan.

\section{Risk Committee}

Risk Committee atau komite risiko adalah sebuah komite yang dibuat oleh dewan komisaris dengan tujuan untuk membantu dewan komisaris khususnya terkait dengan penilaian risiko dan evaluasi manajemen risiko perusahaan. Dalam menjalankan tugasnya komite risiko melakukan rapat untuk membahas segala hal yang terkait pengaplikasian dan review atas manajemen risiko yang telah ditetapkan dan juga mengikuti pelatihan agar kemampuan anggota komite selalu diperbaharui. Menurut Cavezzali \& Gardenal (2015) pelatihan komite risiko adalah proses pembaharuan kemampuan yang dimiliki anggota komite agar mampu menghadapi permasalahan terkait proses Risk assessment di masa mendatang. Sedangkan untuk makna dari rapat komite risiko menurut Cavezzali \& Gardenal (2015) adalah tingkat keaktifan dari komite risiko dalam melakukan pembahasan terkait pengaplikasian dan monitoring manajemen risiko perusahaan. Malik et a. (2020) menemukan bahawa ERM yang di proksikan dengan keberadaan Risk Komiter berpengaruh terhadap kinerja perusahaan.

\section{Risk Assessment}

Risk assessment atau penilaian risiko adalah proses memperkirakan suatu risiko secara kuantitatif maupun kualitatif yang berupa ancaman atau bahaya dan mempersiapkan langkah antisipasinya (FERC, 2016). Dalam aspek Risk assessment di penelitian ini terdapat tiga indikator yang cukup penting untuk menjadi proksi dari ERM yakni frekuensi Risk assessment, tingkat kedalaman Risk assessment, dan metode Risk assessment. Frekuensi penilaian risiko harus dilakukan secara terus menerus, setidaknya pada risiko yang paling dinamis, seperti pasar tertentu dan risiko produksi. Tentu saja, untuk secara efektif menjaga kendali atas risiko, frekuensinya harus disesuaikan dengan tingkat evolusi risiko bisnis. Dan untuk tingkat kedalaman penilaian risiko adalah identifikasi dan penilaian risiko harus dilakukan baik pada tingkat korporasi maupun unit bisnis, mengatur risiko menurut kategori dan subkategori. Sedangkan pengertian untuk metode penilaian risiko bahwa setelah penyaringan risiko kualitatif awal, perusahaan harus melakukan analisis kuantitatif pada risiko yang paling penting (Florio \& Leoni, 2017).

\section{Kinerja Keuangan Perusahaan}

Kinerja keuangan merupakan salah satu analisis yang digunakan untuk mengevaluasi secara benar dan akurat operasional perusahaan sesuai dengan aturan keuangan yang berlaku (Fahmi Irham, 2016). Kinerja perusahaan secara umum diukur menggunakan laba bersih atau menggunakan dasar ukuran lain seperti return on investment atau earnings per share. Pengukuran kinerja dapat 
dilakukan menggunakan laporan keuangan. Pengukuran yang dilakukan dapat menggunakan sistem rating yang relevan. Menurut Hery (2016), Pengukuran kinerja adalah salah satu komponen penting di dalam sistem pengendalian manajemen untuk mengetahui tingkat keberhasilan perusahaan dalam mencapai tujuan yang telah ditetapkan, baik tujuan jangka pendek maupun tujuan jangka panjang.

Berdasarkan beberapa pendapat ahli diatas, maka disimpulkan bahwa kinerja keuangan adalah sebuah hasil usaha yang diraih oleh perusahaan dalam suatu periode akuntansi yang dapat digambarkan menggunakan laporan keuangan perusahaan ataupun rasio-rasio tertentu. Pengukuran kinerja keuangan yang secara umum digunakan memiliki beragam pengukuran, namun secara umum dan mudah adalah pengukuran menggunakan analisis rasio.

\section{Sentralitas CRO dan Kinerja Keuangan Perusahaan}

Sesuai dengan teori agensi (Jensen \& Meckling, 1976), pengelolaan risiko secara menyuluruh merupakan salah satu cara yang digunakan manajemen untuk memenuhi keinginan pemilik saham dalam peningkatan kinerja perusahaan dicapai melalui keberhasilan dalam pengelolaan risiko. Salah satu bentuk komitmen pengelolaan risiko adalah dengan kebaradaan CRO dalam struktur perusahaan. González et al. (2020) yang meneliti di Spanyol tidak menemukan pengaruh sentralitas CRO terhadap kinerja perusahaan.

Sentralitas CRO menunjukkan besaran apresiasi perusahaan terhadap CRO karena telah bertanggungjawab khususnya dalam pengaplikasian dan monitoring manajemen risiko. Sentralitas yang tinggi akan mampu meningkatkan kinerja dari CRO itu sendiri jika didasarkan pada teori agensi. Namun, hasil penelitian terdahulu oleh Cavezzali \& Gardenal (2015) tentang sentralitas CRO menunjukkan hasil tidak signifikan. Hasil ini tentunya bertentang dengan teori agensi yang menunjukkan hasil sebaliknya, dimana semakin besar remunerasi seorang CRO tentunya akan mampu meningkatkan kinerja perusahaan tersebut dengan mampu meminimalisir biaya yang terdampak dari sebuah risiko.

\section{H1: Kinerja keuangan perusahaan dipengaruhi secara signifikan oleh Sentralitas CRO}

\section{Pelatihan Risk Committee dan Kinerja Keuangan Perusahaan}

Teori agensi (Jensen \& Meckling, 1976) menyatakan bahwa salah satu faktor yang mempengaruhi kinerja perusahaan adalah keberhasilan perusahaan dalam melakukan pengelolaan risiko yang dihadapi oleh perusahaan. Dengan adanya pengelolaan risiko, perusahaan dapat menghindari potensi kerugian atau mengurangi dampak dari risiko yang dihadapi. Dengan demikian, nilai perusahaan akan meningkat dengan adanya pengelolaan risiko tersebut.

Pelatihan Risk Committee ditujukan untuk memperbaharui kemampuan Risk Committee sendiri dalam proses penilaian risiko perusahaan. Jika didasarkan pada teori agensi, semakin ahli komite risiko dalam melakukan penilaian risiko maka akan semakin ahli dalam memitigasi risiko perusahaan yang mampu mengurangi pendapatan secaran signifikan. Akan tetapi, hasil penelitian terdahulu menurut Cavezzali \& Gardenal (2015) memberikan hasil yang tidak sejalan dengan teori tersebut, dimana pelatihan ataupun pengalaman profesional dari komite 
risiko tidak berpengaruh secara signifikan terhadap kinerja perusahaan. Oleh karena itu, berdasarkan perbedaan antara teori dengan penelitian terdahulu, maka perumusan hipotesis yang tepat untuk permasalahan di atas adalah sebagai berikut:

H2: Kinerja keuangan perusahaan dipengaruhi secara signifikan oleh Pelatihan Risk Committee

\section{Rapat Risk Committee dan Kinerja Keuangan Perusahaan}

Teori agensi (Jensen \& Meckling, 1976) menyatakan bahwa salah satu faktor yang mempengaruhi kinerja perusahaan adalah keberhasilan perusahaan dalam melakukan pengelolaan risiko yang dihadapi oleh perusahaan. Dengan adanya pengelolaan risiko, perusahaan dapat menghindari potensi kerugian atau mengurangi dampak dari risiko yang dihadapi. Dengan demikian, nilai perusahaan akan meningkat dengan adanya pengelolaan risiko tersebut.

Rapat dalam komite risiko dilakukan untuk melakukan pembahasan ataupun melakukan penilaian risiko yang terjadi dalam perusahaan. Semakin sering dan efektif komite risiko mengadakan pertemuan maka proses penilaian risiko akan semakin baik jika didasarkan pada teori agensi. Namun hasil yang berbeda diberikan oleh penelitian terdahulu oleh Cavezzali \& Gardenal (2015) yang menunjukkan bahwa tingkat keaktifan ataupun frekuensi rapat komite risiko tidak mempengaruhi kinerja keuangan secara signifikan. Oleh karena itu, berdasarkan perbedaan antara teori dengan penelitian terdahulu, maka perumusan hipotesis yang tepat untuk permasalahan di atas adalah sebagai berikut:

H3: Kinerja keuangan perusahaan dipengaruhi secara signifikan oleh Frekuensi Rapat Risk Committee

\section{Frekuensi Risk Assessment dan Kinerja Keuangan Perusahaan}

Jensen \& Meckling (1976) menyatakan bahwa ada dua pihak yaitu agen dan prinsipal dalam sebuah perusahaa. Munculnya agency cost dalam hubungan antara kedua belah pihak tersebut disebabkan adanya perbedaan kepentingan. Pengelolaan manajemen risiko merupakan salah satu bentuk meknisme yang dapat dilakukan oleh pihak agen untuk menunjukan adanya kebijakan dari manajemen untuk meminimalisir risiko untuk dapat menghindari kerugian yang mungkin dihadapi perusahaan sehingga dipandang menjadi nilai tambah bagi perusahaan.

Frekuensi penilaian risiko merupakan satuan yang menunjukkan bahwa seberapa sering komite risiko melakukan penilaiannya khususnya dalam satu periode akuntansi. Menurut Curtis \& Carey (2012) penilaian risiko harus dilakukan secara kontinyu agar mampu mendeteksi risiko-risiko baru selama operasional perusahaan. Hal ini menunjukkan bahwa semakin sering komite melaksanakan penilaian risiko maka biaya yang muncul akibat dari risiko dapat dikendalikan. Teori ini didukung oleh penelitian Florio \& Leoni (2017) yang menunjukkan frekuensi penilaian risiko cenderung mempengaruhi secara signifikan terhadap kinerja perusahaan. Berdasarkan penjabaran tersebut perumusan hipotesis yang tepat untuk permasalahan di atas adalah sebagai berikut: 


\section{H4: Kinerja keuangan perusahaan dipengaruhi secara signifikan oleh Frekuensi Risk assessment}

\section{Level Risk Assessment dan Kinerja Keuangan Perusahaan}

Berdasarkan teori agensi yang dikemukakan oleh Jensen \& Meckling (1976), salah satu yang dapat meningkatkan kinerja perusahaan adalah penerapan manajemen risiko oleh pihak manajemen perusahaan. Manajemen risiko yang terintegrasi dapat mengurangi dampak kerugian yang mungkin akan dihadapi oleh perusahaan. Salah satu komponen penting dalam manejemen risiko adalah tingkat penilaian risiko itu sendiri.

Tingkat kedalaman sebuah penilaian risiko oleh komite risiko adalah sebuah pencapaian yang baik dimana komite mampu melakukan pembagian risiko menjadi sub-bagian dan tidak hanya bagian secara besar perusahaan. Berdasarkan Curtis \& Carey (2012) penilaian risiko yang baik adalah yang semakin mendetail menjadi sub-bagian dari perusahaan. Maka perusahaan dengan penilaian risiko mendetail cenderung lebih siap dalam menghadapi risiko di masa mendatang. Teori ini didukung oleh penelitian Florio \& Leoni (2017) yang menunjukkan tingkat kedalaman penilaian risiko mempengaruhi secara signifikan kinerja perusahaan. Berdasarkan penjabaran tersebut perumusan hipotesis yang tepat untuk permasalahan di atas adalah sebagai berikut:

H5: Kinerja keuangan perusahaan dipengaruhi secara signifikan oleh Tingkat kedalaman Risk assessment

\section{Metode Risk Assessment dan Kinerja Keuangan Perusahaan}

Teori agensi (Jensen \& Meckling (1976) menunukan bahwa salah satu yang dapat meningkatkan kinerja perusahaan adalah penerapan manajemen risiko oleh pihak manajemen perusahaan. Manajemen risiko yang terintegrasi dapat mengurangi dampak kerugian yang mungkin akan dihadapi oleh perusahaan. Salah satu komponen penting dalam manejemen risiko adalah penentuan metode dalam mengukur risiko yang dihadap perusahaan.

Metode penilaian risiko adalah metode yang digunakan dalam melakukan penilaian akan suatu risiko yang dilakukan secara kualitatif dan kuantitatif. Perusahaan dengan komite risiko yang melakukan penilaian risiko dengan metode kualitatif dan kuantitatif tentunya akan memiliki kesiapan yang lebih baik dalam menghadapi risiko perusahaan (Curtis \& Carey, 2012). Hal ini memungkinkan karena perusahaan sudah memperkirakan biaya yang akan keluar saat menghadapi risiko tersebut. Sejalan dengan hasil penelitian oleh Florio \& Leoni (2017), menunjukkan kinerja perusahaan secara signifikan dipengaruhi oleh metode yang digunakan dalam melakukan penilaian risiko. Berdasarkan penjabaran tersebut perumusan hipotesis yang tepat untuk permasalahan di atas adalah sebagai berikut:

H6 : Kinerja keuangan perusahaan dipengaruhi secara signifikan oleh Metode Risk assessment

\section{METODOLOGI PENELITIAN}


Penelitian ini bertujuan meniliti pengaruh ERM terhadap kinerja keuangan perusahaann. Data populasi yang digunakan adalah seluruh perusahaan BUMN di Indonesia periode 2016-2019 yang termasuk dalam indeks BUMN20 khususnya pada perusahaan non-keuangan. Jenis perusahaan ini dipilih berdasarkan fenomena dimana perusahaan ini memiliki kewajiban untuk menerapkan ERM sehingga pelaporan penerapan ERM dalam laporan tahunan lebih lengkap dan kompleks. Pemilihan sampel tidak dilakukan seperti pada penelitian terdahulu oleh Cavezzali \& Gardenal (2015) dan Florio \& Leoni (2017) yang lebih berfokus pada perusahaan perbankan.

Pada penelitian ini, dipilih sampel perusahaan BUMN karena adanya mandatory disclosure dari kementerian BUMN seperti pada perusahaan perbankan untuk menerapkan dan melaporkan terkait ERM dalam laporan tahunan perusahaan. Metode sampling yang digunakan adalah purposive sampling. Adapun perusahaan yang terpilih pada jumlah awal terdapat 20 perusahaan, setelah diseleksi dengan kriteria seperti perusahaan non-keuangan, sampel menjadi 16 perusahaan dengan jumlah periode selama 2015-2019 sehingga total sampel yang digunakan penelitian menjadi 80 sampel. Dalam proses pengolahan data, dilakukan treatment agar data memenuhi uji kualitas dilakukan outlier. Data setelah dilakukan outlier menjadi 59 sampel penelitian.

Pengukuran variabel dependen yaitu kinerja perusahaan diproksikan dengan ROA, sedangkan variabel independen yaitu ERM di ukur dari indikator ERM dengan konten analisis dengan jumlah 6 indikator yaitu Sentralitas CRO (Chief Risk Officer), pelatihan komite risiko, rapat komiter risiko, frekuensi penilaian risiko, level penilaian risiko, dan metode peniliaian risiko.

\section{Kinerja Keuangan Perusahaan}

Kinerja keuangan perusahaan adalah bagian penting dalam menentukan tingkat keberhasilan target jangka pendek dan jangka panjang perusahaan (Hery, 2016). Kinerja keuangan perusahaan diukur menggunakan ROA dengan merujuk pada laporan keuangan perusahaan. Skala pengukuran variabel adalah skala rasio dan perhitungan rumus seperti ditunjukan Rumus 1.

$$
\begin{aligned}
& \text { Rumus 1. Perhitungan ROA }
\end{aligned}
$$

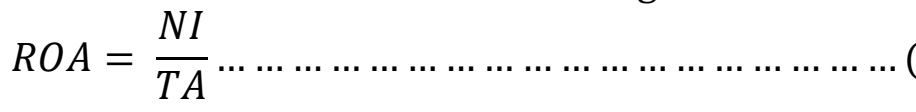

Keterangan :

ROA : Return on Asset

$\mathrm{NI} \quad$ : Net Income

TA : Total Assets

\section{CROcentrality}

Sentralitas CRO adalah seberapa besar urgensi kepentingan yang dimiliki oleh perusahaan khususnya terkait pengukuran risiko perusahaan (Cavezzali \& Gardenal, 2015). CROcentrality terkait besaran remunerasi CRO dibandingkan dengan CFO, diberi nilai 1 apabila melebihi 50\% dan 0 apabila sebaliknya.

\section{RCexperience}


Pelatihan komite risiko adalah proses pembaharuan kemampuan yang dimiliki anggota komite agar mampu menghadapi permasalahan terkait proses Risk assessment di masa mendatang (Cavezzali \& Gardenal, 2015). RCexperience terkait pelatihan yang dilakukan anggota komite risiko, dengan minimal satu kali dalam setahun. Diberi nilai 1 jika memenuhi dan 0 apabila sebaliknya.

\section{RCmeeting}

Tingkat keaktifan dari komite risiko dalam melakukan pembahasan terkait pengaplikasian dan monitoring manajemen risiko perusahaan (Cavezzali \& Gardenal, 2015). RCmeeting adalah minimal rapat yang dilakukan dalam satu periode akuntansi. Minimal satu kali dalam satu bulan. Diberi nilai 1 jika memenuhi dan 0 apabila sebaliknya.

\section{RAfrequency}

Frekuensi penilaian risiko adalah proses yang dilakukan secara terus menerus, setidaknya pada risiko yang paling dinamis, seperti pasar tertentu dan risiko produksi. Untuk secara efektif menjaga kendali atas risiko, frekuensinya harus disesuaikan dengan tingkat evolusi risiko bisnis (Florio \& Leoni, 2017). RAfrequency adalah frekuensi penilaian risiko, minimal dilakukan 2 kali dalam satu periode. Diberi nilai 1 jika memenuhi dan 0 apabila sebaliknya.

\section{RAlevel}

Tingkat kedalaman penilaian risiko adalah identifikasi dan penilaian risiko harus dilakukan baik pada tingkat korporasi maupun unit bisnis, mengatur risiko menurut kategori dan subkategori (Florio \& Leoni, 2017). RAlevel adalah kedalaman prosedur, dimana terdapat pembagian risiko secara mendetail. Diberi nilai 1 jika memenuhi dan 0 apabila sebaliknya.

\section{RAmethod}

Metode yang digunakan dalam melakukan penilaian akan suatu risiko yang dilakukan secara kualitatif dan kuantitatif (Florio \& Leoni, 2017). RAmethod mengacu pada metodologi untuk penilaian, yang dapat bersifat kualitatif maupun kuantitatif. Diberi nilai 1 jika menggunakan kedua metode dan 0 apabila hanya salah satu.

\section{Size}

Ukuran perusahaan adalah ukuran yang dapat membedakan perusahaan berdasarkan total modal, total aset, dan pendapatan. Semakin besar ketiga hal tersebut, semakin kuat kondisi perusahaan (Basyaib, 2007). Pengukuran ukuran perusahaan menggunakan logaritma natural dari keseluruhan aset perusahaan. Berikut rumus yang digunakan untuk menghitung ukuran peusahaan disajikan dalam Rumus 2.

Rumus 2. Rumus Menghitung Ukuran Perusahaan

$$
\text { Size }=\ln \text { total asset }
$$

\section{Leverage}

Leverage mengacu pada penggunaan aset dan sumber modal oleh 
perusahaan dengan biaya tetap untuk meningkatkan potensi keuntungan pemegang saham (Sartono, 2008). Pengukuran leverage menggunakan debt to equity ratio yakni perbandingan antara total hutang dibanding total ekuitas perusahaan yang ditunjukan dalam Rumus 3.

$$
\begin{aligned}
& \text { Rumus 3. Rumus Menghitung Leverage } \\
& D E R=\frac{\text { total hutang }}{\text { total ekuitas }}
\end{aligned}
$$

\section{Model Regresi}

Variabel pada penelitian ini merupakan kombinasi dari penelitian oleh Florio \& Leoni (2017) dan Cavezzali \& Gardenal (2015) serta dilakukan modifikasi pengukuran yang digunakan. Adapun gabungan ini dipilih karena mampu menggambarkan enterprise risk management yang diterapkan perusahaan dilihat dari sudut pandang tiap komponen yang mewakili. Rumus 4 menujukan persamaan model regresi yang dijadikan acuan dalam penelitian.

$$
\begin{gathered}
\text { Rumus 4. Mode Regresi } \\
\text { ROA }_{i t}=\alpha+\beta_{1} \text { CROcentrality }_{i t}+\beta_{2} \text { RCexperience }_{i t}+\beta_{3} \text { RCmeeting }_{i t} \\
+\beta_{4} \text { RAfrequency }_{i t}+\beta_{5} \text { RAlevel }_{i t}+\beta_{6} \text { RAmethod }_{i t} \\
+\beta_{7} \text { Size }_{i t}+\beta_{8} \text { Leverage }_{i t}+e \ldots \ldots \ldots \ldots(4)
\end{gathered}
$$

\section{HASIL DAN PEMBAHASAN}

Pada table 1 menunjukkan statistika deskriptif untuk variabel dependen, independen, dan kontrol. Perusahaan yang dijadikan sampel menunjukkan ratarata kinerja yang ditunjukkan dengan nilai ROA sebesar 0,033 dan penyebaran data sebesar 0,031. Rata-rata yang lebih tinggi dari nilai penyebaran mengindikasikan penyebaran data lebih homogen yang menunjukkan bahwa setiap perusahaan mendapatkan laba perusahaan yang cenderung kecil. Kinerja terbaik ditunjukkan oleh PT Telkom Indonesia pada tahun 2018 dengan nilai 12,5\% dan kinerja terburuk ditunjukkan oleh PT Krakatau Steel pada tahun 2016 dengan nilai $-4,8 \%$.

Tabel 1. Statistik Deskriptif

\begin{tabular}{lllll}
\hline Variabel & Mean & Max & Min & SD \\
\hline CROs & 0,29 & 1 & 0 & 0,457 \\
RCexp & 0,54 & 1 & 0 & 0,502 \\
RCmeet & 0,69 & 1 & 0 & 0,464 \\
RAfreq & 0,61 & 1 & 0 & 0,492 \\
RAlvl & 0,69 & 1 & 0 & 0,464 \\
RAmthd & 0,049 & 1 & 0 & 0,504 \\
ROA & 0,033 & 0,125 & $0,048)$ & 0,031 \\
Size* & 4.711 .106 .736 & 22.120 .800 .000 & 323.622 .40 & 4.049 .728 .779 \\
& & & 0 & \\
Leverage & 1,584 & 3,353 & 0,216 & 0,954 \\
\hline
\end{tabular}




\section{$\mathrm{N} \quad 59$ \\ * Dalam Puluhan RIbu}

Sumber: Data Diolah (2021)

Lalu jika dilihat pada tabel, jika nilai rata-rata tiap variabel independent dikalikan dengan jumlah sampel akan menunjukkan sampel yang memenuhi kriteria dari variabel independent tersebut, seperti pada variabel sentralitas CRO ditunjukkan sebanyak 17 sampel telah memiliki tingkat sentralitas CRO yang tinggi, pada variabel pelatihan komite risiko dan rapat komite risiko ditunjukkan dengan dengan perusahaan yang rutin melaksanakan pelatihan dan rapat sebanyak 32 dan 41 sampel. Adapun pada unsur penilaian risiko seperti frekuensi penilaian, level, dan menerapkan kedua metode ditunjukkan sebanyak 36 , 41, dan 29 sampel secara berturut-turut.

Perusahaan yang dijadikan sampel telah diterapkan variabel kontrol seperti ukuran perusahaan dan leverage agar pengaruh dari kedua variabel tersebut dalam penelitian telah diperhitungkan dan lebih banyak memberikan gambaran secara menyeluruh terhadap pengaruh variabel independent terhadap variabel dependen.

Tabel 2. Hasil Uji Kualitas Data

\begin{tabular}{lcccccc}
\hline \multicolumn{1}{c}{ Variabel } & Hasil Uji KS & Tolerance & VIF & DW & dU & 4-dU \\
\hline CROs & & 0,876 & 1,142 & & & \\
RCexp & & 0,724 & 1,382 & & & \\
RCmeet & & 0,780 & 1,282 & & & \\
RAfreq & 0,067 & 0,844 & 1,185 & 1,863 & 1,8091 & 2,1909 \\
RAlvl & & 0,853 & 1,172 & & & \\
RAmthd & & 0,880 & 1,136 & & & \\
Size & & 0,652 & 1,534 & & & \\
Leverage & & 0,754 & 1,326 & & & \\
\hline N & 59 & & & & & \\
\hline
\end{tabular}

Sumber: Data Diolah (2021)

Dalam pengujian kualitas data diawali dengan pengujian normalitas, pada penelitian ini pengujian normalitas menggunakan pengujian Kolmogorov-Smirnov KS), pada tabel 2 menunjukkan bahwa nilai dari hasil uji KS adalah 0,067 dan telah melebihi 0,05 sehingga data telah terdistribusi secara normal. Lalu pengujian dilanjutkan dengan uji multikolinearitas, indicator yang dilihat pada pengujian ini adalah nilai tolerance dan VIF dari masing-masing variabel, jika merujuk pada tabel 2, maka data tidak terjadi multikolinearitas atau terdapat hubungan antara variabel bebas dimana nilai tolerance $>0,1$ dan nilai VIF $<10$.

Gambar 1. Hasil Uji Heteroskedastisitas 


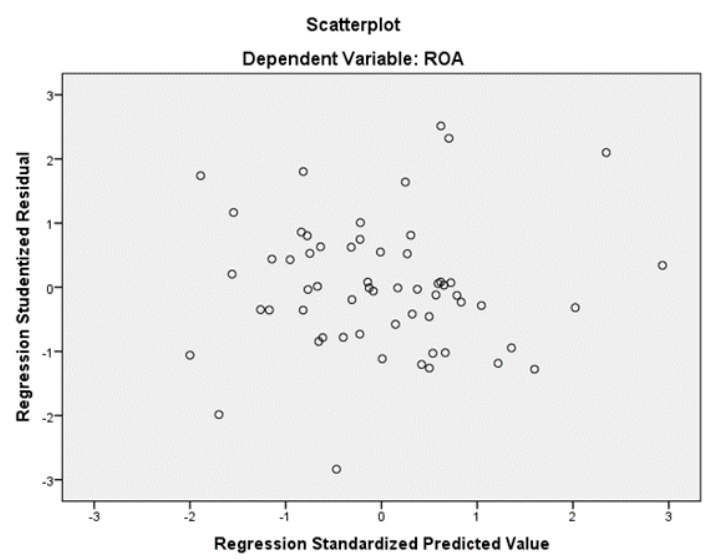

Sumber: Data Diolah (2021)

Untuk pengujian heteroskedastisitas merujuk pada gambar 1 yang memberikan gambaran bahwa data menyebar secara acak di antara 0 dan sumbu $\mathrm{Y}$, selain itu tidak terbentik sebuah pola tertentu seperti zig-zag ataupun garis lurus sehingga model telah terbebas dari masalah heterokedastisitas ataupun data bersifat homogen. Pengujian kualitas data yang terakhir adalah uji autokorelasi, hasil nilai Durbin Watson (DW) dibandingkan dengan nilai dU dan 4-dU yang akan menentukan data terbebas masalah autokorelasi. Pada tabel 2 menunjukkan nilai DW sebesar 1,863 dan nilai dU dengan 6 variabel independen, dan N sebanyak 59 pada tabel DurbinWatson menunjukkan nilai 1,8091 dan nilai 4-dU yaitu 2,1909. Sehingga data dalam penelitian telah terbebas dari masalah autokorelasi. SPSS.

Berikut ini adalah hasil pengujian regresi berganda menggunakan software

Tabel 3. Tabel Hasil Pengujian

\begin{tabular}{llrl}
\multicolumn{3}{c}{ Uji t } \\
\cline { 2 - 3 } Model & \multicolumn{1}{c}{$\mathrm{t}$} & \multicolumn{1}{c}{ Sig. } & VIF \\
\cline { 2 - 3 } 1 & & & \\
\hline (Constant) & -1.196 & .237 & \\
CROs & 1.536 & .131 & 1.142 \\
RCexp & 1.161 & .251 & 1.382 \\
RCmeet & -3.249 & .002 & 1.282 \\
RAfreq & -.230 & .819 & 1.185 \\
RAlvl & -.472 & .639 & 1.172 \\
RAmthd & 1.488 & .143 & 1.136 \\
Size & 1.486 & .143 & 1.534 \\
Leverage & -1.246 & .219 & 1.326 \\
\hline Rsquare & 0.328 \\
\hline
\end{tabular}

Sumber: Data Diolah (2021)

Hasil penelitian yang pertama adalah hasil dari pengujian koefisien determinasi atau uji R Square. Hasil pengujian ini akan menunjukkan seberapa besar variabel independent dapat memberikan informasi untuk memprediksi 
variabel dependen. Jika merujuk pada tabel 3, nilai R Square yang ditunjukkan sebesar 0,328 yang memiliki makna bahwa variabel independen yang digunakan dalam penelitian telah mampu untuk menjelaskan variabel kinerja perusahaan ditunjukkan dengan mampu menjelaskan sebesar 32,8\% terhadap kinerja perusahaan dan sisa sebesar $67,2 \%$ dijelaskan variabel lainnya.

Pengujian selanjutnya adalah uji t. Pada uji t ini akan membandingkan nilai masing-masing $t$ hitung variabel independent dengan nilai $t$ tabel atau dengan membandingkan nilai Sig dengan standar error penelitian yakni 0,05 (5\%). Menurut hasil pengujian signifikan parameter individual atau uji t untuk variabel CROs menunjukan nilai signifikansi sebesar 0,131. Maka disimpulkan bahwa kinerja perusahaan tidak dipengaruhi secara signifikan oleh sentralitas CRO, maka hipotesis pertama (H1) ditolak. Hasil ini sependapat dengan penelitian oleh Cavezzali \& Gardenal (2015) yang memberikan penyataan bahwa kinerja perusahaan tidak dipengaruhi secara signifikan oleh sentralitas CRO. Hasil ini mengindikasikan bahwa kinerja perusahaan BUMN non keuangan di Indonesia tidak dipengaruhi secara signifikan oleh sentralitas CRO. Sehingga jika sentralitas CRO meningkat, maka kinerja perusahaan dapat meningkat pula namun tidak terlalu signifikan. Merujuk pada data, dimana perusahaan Wijaya Karya selama tahun 2016-2017 menunjukkan tingkat sentralitas yang tinggi namun tidak meningkatkan kinerja perusahaan melainkan menurun secara tidak signifikan dan seperti perusahaan Adhi Karya dimana CRO mereka memiliki remunerasi yang cukup tinggi dibandingkan dengan CFO selama 2015-2019, namun kinerja perusahaan yang ditunjukkan mengalami penurunan yang tidak signifikan.

Berdasarkan tabel 3 menunjukan bahwa signifikansi variabel RCexp sebesar 0,251. Maka disimpulkan bahwa kinerja perusahaan tidak dipengaruhi secara signifikan oleh pelatihan komite risiko, maka hipotesis kedua (H2) ditolak. Hasil ini sependapat dengan penelitian oleh Cavezzali \& Gardenal (2015) yang memberikan penyataan bahwa kinerja perusahaan tidak dipengaruhi secara signifikan oleh pelatihan komite risiko. Hasil ini mengindikasikan bahwa kinerja perusahaan BUMN non keuangan di Indonesia tidak dipengaruhi secara signifikan oleh pelatihan komite risiko. Sehingga jika pelatihan komite risiko meningkat, maka kinerja perusahaan dapat meningkat pula namun tidak terlalu signifikan. Merujuk pada data, dimana perusahaan Adhi Karya pada tahun 2017-2019 menunjukkan tingkat pelatihan yang tinggi namun kinerja perusahaan tidak mengalami peningkatan dan cenderung menurun secara tidak signifikan atau pada perusahaan Aneka Tambang yang rutin mengikuti pelatihan komite risiko selama 2015-2019, kinerja perusahaan yang ditunjukkan tidak mengalami peningkatan namun mengalami penurunan secara tidak signifikan.

Menurut hasil pengujian signifikan parameter individual atau uji $t$ menunjukan bahwa nilai signifikansi variabel RCmeet sebesar 0,002 dimana lebih kecil dari nilai signifikansi penelitian sebesar 0,05. Maka disimpulkan bahwa kinerja perusahaan dipengaruhi secara signifikan oleh frekuensi rapat komite risiko, maka hipotesis ketiga (H3) diterima. Hasil ini tidak sependapat dengan penelitian oleh Cavezzali \& Gardenal (2015) yang memberikan penyataan bahwa kinerja perusahaan dipengaruhi secara tidak signifikan oleh pelatihan komite risiko. Hasil ini mengindikasikan bahwa kinerja perusahaan BUMN non keuangan di Indonesia dipengaruhi secara signifikan oleh frekuensi rapat komite risiko. 
Sehingga jika frekuensi rapat komite risiko meningkat, maka kinerja perusahaan dapat meningkat cukup signifikan. Hasil ini memungkinkan dimana dari peningkatan frekuensi rapat mampu memberikan nilai ekonomis yang lebih tinggi dibandingkan dengan biaya yang dikeluarkan. Selain itu terdapat kemungkinan bahwa rapat yang diadakan berjalan secara efektif. Adapun solusi yang dapat dilakukan oleh perusahaan adalah dengan memaksimalkan rapat komite dengan melakukan prinsip 3E yakni ekonomis, efisien, dan efektif sehingga biaya yang timbul seiringan dengan frekuensi rapat sebanding dengan hasil atau output yang dihasilkan dari rapat tersebut.

Menurut hasil pengujian menunjukan bahwa nilai signifikansi variebel RAfreq sebesar 0,819. Maka disimpulkan bahwa kinerja perusahaan tidak dipengaruhi secara signifikan oleh frekuensi penilaian risiko, maka hipotesis keempat (H4) ditolak. Hasil ini sependapat dengan penelitian oleh Florio \& Leoni (2017) yang memberikan penyataan bahwa kinerja perusahaan tidak dipengaruhi secara signifikan oleh frekuensi penilaian risiko. Hasil ini mengindikasikan bahwa kinerja perusahaan BUMN non keuangan di Indonesia tidak dipengaruhi secara signifikan oleh frekuensi penilaian risiko. Sehingga jika frekuensi penilaian risiko meningkat, maka kinerja perusahaan dapat meningkat pula ataupun turun namun tidak terlalu signifikan. Merujuk pada data, perusahaan Jasamarga pada tahun 2017-2019 menunjukkan frekuensi penilaian risiko yang memenuhi standar namun tidak meningkatkan kinerja perusahaan justru menurun secara tidak signifikan dan seperti perusahaan PP yang telah melakukan penilaian risiko sesuai dengan standar selama 2016 dan 2017, namun kinerja perusahaan yang ditunjukkan tidak mengalami kenaikan, justru mengalami penurunan secara tidak signifikan.

Menurut hasil uji regresi menunjukan bahwa nilai signifikansi variabel RAlvl sebesar 0,639. Maka disimpulkan bahwa kinerja perusahaan tidak dipengaruhi secara signifikan oleh tingkat kedalaman penilaian risiko, maka hipotesis kelima (H5) ditolak. Hasil ini sependapat dengan penelitian oleh Florio \& Leoni (2017) yang memberikan penyataan bahwa kinerja perusahaan tidak dipengaruhi secara signifikan oleh tingkat kedalaman penilaian risiko. Hasil ini mengindikasikan bahwa kinerja perusahaan BUMN non keuangan di Indonesia tidak dipengaruhi secara signifikan oleh tingkat kedalaman penilaian risiko. Sehingga jika tingkat penerapan kedalaman penilaian risiko meningkat, maka kinerja perusahaan dapat meningkat pula namun tidak terlalu signifikan. Merujuk pada data, perusahaan Waskita di tahun 2015-2016 menunjukkan tingkat kedalaman penilaian risiko yang baik namun kinerja yang dihasilkan tidak berubah cukup signifikan. Hal serupa ditemukan pada perusahaan Wijaya Karya pada tahun yang sama telah menerapkan penilaian risiko yang mendetail namun kinerja perusahaan yang ditunjukkan tidak mengalami kenaikan sedangkan mengalami penurunan secara tidak signifikan.

Hasil pengujian regresi menunjukan bahwa signifikansi variabel RAmthd sebesar 0,143 dimana lebih besar dari nilai signifikansi penelitian sebesar 0,05. Maka disimpulkan bahwa kinerja perusahaan tidak dipengaruhi secara signifikan oleh metode penilaian risiko, maka hipotesis keenam (H6) ditolak. Hasil ini tidak sependapat dengan penelitian oleh Florio \& Leoni, (2017) yang memberikan penyataan bahwa kinerja perusahaan dipengaruhi secara signifikan positif oleh 
metode penilaian risiko. Hasil ini mengindikasikan bahwa kinerja perusahaan BUMN non keuangan di Indonesia tidak dipengaruhi secara signifikan oleh metode penilaian risiko. Sehingga jika metode penilaian risiko menggunakan kedua metode yakni kualitatif dan kuantitatif, maka kinerja perusahaan dapat meningkat pula namun tidak terlalu signifikan. Hasil ini memungkinkan dimana dari penggunaan metode yang lengkap memberikan nilai manfaat ekonomis yang tidak terlalu signifikan. Sehingga peningkatan kinerja tidak terlalu dirasakan.

Merujuk pada tabel 3, ditunjukkan bahwa pada variabel CROs, RCexp, RAfreq, RAlvl, dan RAmthd menunjukkan nilai t hitung $<\mathrm{t}$ tabel dan nilai $\operatorname{Sig}(\mathrm{t})>$ 0,05 sehingga menghasilkan bahwa hipotesis 1,2, 4, 5, dan 6 ditolak. Hasil ini memungkinkan disebabkan penerapan dari tiap variabel dalam perusahaan tidak memberikan timbal balik secara optimal sehingga manfaat ekonomis yang diberikan tidak sebanding dengan yang diberikan. Hasil ini sejalan dengan penelitian terdahulu oleh Cavezzali \& Gardenal (2015) pada hipotesis 1 dan 2, dan hasil serupa pada penelitian oleh Florio \& Leoni (2017) pada hipotesis 4 dan 5, namun berbeda pada hipotesis 6, dimana pada penelitian sebelumnya menunjukkan pengaruh signifikan.

Pada penelitian ini juga dilakukan pengujian secara simultan atau uji $\mathrm{F}$, merujuk pada tabel 3 nilai $\mathrm{F}$ hitung menunjukkan lebih besar dibanding $\mathrm{F}$ tabel dan nilai $\operatorname{Sig}(\mathrm{F})<0,05$ maka secara simultan variabel independent yang terkait enterprise risk management yang telah dijabarkan diatas memengaruhi signifikan terhadap variabel dependen penelitian yakni kinerja keuangan perusahaan. Hasil ini menunjukkan bahwa kebijakan yang tepat dalam pelaksanaan variabel independent akan memberikan dampak signifikan secara simultan atau keseluruhan.

\section{SIMPULAN}

Penelitian bertujuan untuk menganalisis pengaruh Enterprise Risk Management terhadap kinerja perusahaan khususnya pada perusahaan BUMN non keuangan yang terdaftar pada Bursa Efek Indonesia. Setelah dilaksanakan proses analisis data dan pegujian regresi linier menggunakan spss disimpulkan bahwa dari 6 variabel independen terkait enterprise risk management hanya variabel rapat komite risiko yang berpengaruh signifikan. Sedangkan 5 variabel lainnya yaitu sentralitas CRO, pelatihan risk committee, frekuensi risk assessment, tingkat kedalaman risk assessment, dan metode metode risk assessment tidak berpengaruh terhadap kinerja keuangan perusahaan.

Adapun kemungkinan hasil tersebut didasarkan pada penerapan dari enterprise risk management itu sendiri belum maksimal sehingga manfaat ekonomi yang dihasilkan tidak lebih besar dari biaya yang dikeluarkan. Sehingga yang dapat dilakukan bagi perusahaan adalah dengan meningkatkan penerapan enterprise risk management agar pengaruh yang dihasilkan dapat lebih terdeskripsikan dengan jelas.

Penelitian ini tidak luput dari kesalahan agar dapat menjadi pembaharuan pada penelitian selanjutnya, seperti pengukuran variabel untuk enterprise risk management dapat menggunakan pengukuran lain agar jangkauan yang lebih 
umum dilaporkan pada laporan tahunan seperti tingkat maturitas manajemen risiko ataupun menggunakan pengukuran yang berbeda pada kinerja keuangan perusahaan. Selain itu, penelitian selanjutnya diharapkan untuk menambah objek penelitian dan membagi pada sektor-sektor perusahaan agar variabel-variabel di luar penelitian yang mempengaruhi dapat diminimalisir pengaruhnya.

\section{DAFTAR PUSTAKA}

Adi, T. W. (2020). The Influence of Risk Management on Financial Performance and Firm Value: A Case Study on Companies of Crude Petroleum and Natural Gas Production Sector Listed at the IDX 2016 - 2019. European Journal of Business and Management, 12(23), 126-133. https://doi.org/10.7176/EJBM/12-23-14

Ali, M. M., Hamid, N. S. A., \& Ghani, E. K. (2019). Examining the relationship between enterprise risk management and firm performance in Malaysia. International Journal of Financial Research, 10(3), 239-251. https://doi.org/10.5430/ijfr.v10n3p239

Ayuningtyas, D. (2019). Kinerja Emiten BUMN, BRI Juara Laba \& Telkom Jawara Omzet. Retrieved November 30, 2020, from https://www.cnbcindonesia.com/ website: https://www.cnbcindonesia.com/market/20190808102836-17-

90618/kinerja-emiten-bumn-bri-juara-laba-telkom-jawara-omzet

Basyaib, F. (2007). Keuangan Perusahaan Pemodelan Menggunakan Microsoft Excel. Jakarta: Kencana Prenada Media Group.

Bertinetti, G. S., Cavezzali, E., \& Gardenal, G. (2013). The Effect of the Enterprise Risk Management Implementation on the Firm Value of European Companies. SSRN Electronic Journal, (August). https://doi.org/10.2139/ssrn.2326195

Cavezzali, E., \& Gardenal, G. (2015). Risk Governance and Performance of the Italian Banks: An Empirical Analysis. SSRN Electronic Journal. https://doi.org/10.2139/ssrn.2684516

COSO ERP. (2004). Enterprise Risk Management-Integrated Framework. In Sarbanes-Oxley Guide for Finance and Information Technology Professionals. New York. https://doi.org/10.1002/9781119201939.app4

COSO. (2017). Enterprise Risk Management. Integrating with strategy and performance. The Committee of Sponsoring Organizations of the Treadway Commission, (June), 16. Retrieved from https://www.coso.org/Documents/2017-COSO-ERM-Integrating-withStrategy-and-Performance-Executive-Summary.pdf

CRMS. (2019). Survei Nasional Manajemen Risiko 2019. Retrieved from www.crmsindonesia.org

Curtis, P., \& Carey, M. (2012). Risk Assessment in Practice. Retrieved November 23, 2020,

from https://www2.deloitte.com/content/dam/Deloitte/global/Documents/Gov ernance-Risk-Compliance/dttl-grc-riskassessmentinpractice.pdf

Fahmi Irham. (2016). Manajemen Risiko Teori,Kasus dan Solusi. Bandung: Alfabeta. 
Federal Energy Regulatory Commission. (2016). Risk-Informed Decision Making Guidelines. Chapter 3, Risk Assessment.

Florio, C., \& Leoni, G. (2017). Enterprise risk management and firm performance: The Italian case. The British Accounting Review, 49(1), 56-74. https://doi.org/10.1016/j.bar.2016.08.003

Hery. (2016). Analisis Laporan Keuangan. Jakarta: PT. Gramedia Widiasarana Indonesia.

Jensen, M. C., \& Meckling, W. H. (1976). Theoy of The Firm : Managerial Behavior, Agency Costs And Ownership Structure. Journal of Financial Economics, 3, 305-360.

Kashif Shad, M., \& Lai, F.-W. (2019). Enterprise Risk Management Implementation and Firm Performance: Evidence from the Malaysian Oil and Gas Industry. International Journal of Business and Management, 14(9), 47. https://doi.org/10.5539/ijbm.v14n9p47

Malik, M. F., Zaman, M., \& Buckby, S. (2020). Enterprise risk management and firm performance: Role of the risk committee. Journal of Contemporary Accounting and Economics, 16(1). https://doi.org/10.1016/j.jcae.2019.100178

Millet, J. D. (1954). Management in the Public Services: The Quest For Performance. American Political Science Review, 48(4), 1173.

Otero González, L., Durán Santomil, P., \& Tamayo Herrera, A. (2020). The effect of Enterprise Risk Management on the risk and the performance of Spanish listed companies. European Research on Management and Business Economics. https://doi.org/10.1016/j.iedeen.2020.08.002

Pranatha, M. A., Moeljadi, M., \& Hernawati, E. (2019). Penerapan Enterprise Risk Management Dalam Meningkatkan Kinerja Keuangan Di Perusahaan "Xyz." Jurnal Ekonomi Dan Bisnis, 5(1), 17. https://doi.org/10.35590/jeb.v5i1.686

Sartono, A. (2008). Manajemen Keuangan Teori dan Aplikasi. Yogyakarta: BPFE.

Sax, J., \& Torp, S. S. (2015). Speak up! enhancing risk performance with enterprise risk management, leadership style and employee voice. Management Decision, 53(7), 1452-1468. https://doi.org/10.1108/MD-10-2014-0625

Senol, Z., \& Karaca, S. S. (2017). The Effect of Enterprise Risk Management on Firm Performance: A Study of Turkey. In Financial Studies. Retrieved from https://ideas.repec.org/a/vls/finstu/v21y2017i2p6-30.html

Songling, Y., Ishtiaq, M., \& Anwar, M. (2018). Enterprise Risk Management Practices and Firm Performance, the Mediating Role of Competitive Advantage and the Moderating Role of Financial Literacy. Journal of Risk and Financial Management, 11(3), 35. https://doi.org/10.3390/jrfm11030035

Terry, G. R. (1977). Principles of Management, seventh Edition (7th ed.). Illinois: R. D. Irwin.

Vaughan, E. ., \& Elliot, C. M. (1978). Fundamentals of Risk and Insurance. Toronto: John Wiley \& Sons Inc. 